\title{
Conceptual Framework of Inquiry-Creative-Process Learning Model to Promote Critical Thinking Skills of Physics Prospective Teachers
}

\author{
Wahyudi $^{1}$, N. N. S. P. Verawati ${ }^{1 *}$, S. Ayub ${ }^{1}$, S. Prayogi ${ }^{2}$ \\ ${ }^{1}$ Program Studi Pendidikan Fisika, Fakultas Keguruan dan IImu Pendidikan, \\ Universitas Mataram, Indonesia \\ ${ }^{2}$ Program Studi Pendidikan Fisika, Institut Keguruan dan IImu Pendidikan Mataram, Indonesia
}

Submitted: 9 July 2018. Revised: 28 December 2018. Accepted: 1 January 2019

\begin{abstract}
Critical thinking has become a major competency of higher education learning in Indonesia; therefore, a specific learning model that is oriented towards improving students' critical thinking skills is important to be developed. This study aims to develop an Inquiry Creative Process (ICP) learning model to promote critical thinking skills of physics prospective teachers. This research is the first step of development research which produce learning model with valid criteria on content validity and construct validity aspects. The validation of ICP learning model has been done through focus group discussion (FGD) mechanism involving 5 experts as validator. The data of the validation results of the model were analyzed descriptively by averaging the validation score. Validation results show that the validity level (Va) of 4.12. The conceptual framework and validation results of the ICP learning model are described in this article.
\end{abstract}

\section{ABSTRAK}

Berpikir kritis telah menjadi kompetensi utama pembelajaran tingkat pendidikan tinggi di Indonesia, sehingga model pembelajaran yang spesifik berorientasi ke arah peningkatan keterampilan berpikir kritis mahasiswa menjadi penting untuk dikembangkan. Penelitian ini bertujuan mengembangkan model pembelajaran Inquiry Creative Process (ICP) untuk melatih keterampilan berpikir kritis mahasiswa calon guru fisika. Penelitian ini merupakan langkah awal penelitian pengembangan yang menghasilkan produk model pembelajaran dengan kriteria valid pada aspek-aspek validitas isi (content validity) dan validitas konstruk (construct validity). Validasi model pembelajaran ICP dilakukan melalui mekanisme focus group discussion (FGD) dengan melibatkan 5 orang pakar selaku validator. Data hasil validasi model dianalisis secara deskriptif dengan merata-rata skor hasil validasi. Hasil validasi menunjukkan tingkat kevalidan (Va) model pembelajaran ICP sebesar 4,12 berada pada kategori valid. Kerangka konseptual dan hasil validasi model pembelajaran ICP dijabarkan dalam artikel ini.

Keywords: Critical Thinking; Inquiry-Creative-Process; Physics Prospective Teachers

\section{INTRODUCTION}

One of the essential skills that the learners must have in the 21 st century is critical thinking skill (Partnership 21st Century Skills, 2011). In some countries, critical thinking has become a major focus and competency in learning at all levels of their education (Schmaltz, Jansen, \& Wenckowski, 2017).

*Correspondence Address:

Jl. Majapahit No. 62 Mataram, Kode Pos 83115

E-mail: veyra@unram.ac.id
In Indonesia, critical thinking has also become a very important part of the competence to be achieved at the higher education level, as set forth in the Regulation of the Minister of Research, Technology and Higher Education of the Republic of Indonesia. Global Citizenship Education (GCE) recommends that universities should seek to facilitate students to analyze issues critically, identify creative and innovative solutions. A function of higher education is to teach students to think. University accreditation boards in some advanced countries, for example, the National Association of Industrial Technology (NAIT), the Accreditation Board of 
Engineering and Technology (ABET), and the International Technology Education Association (ITEA) recognize competencies such as critical thinking, problem solving, communication, and teamwork in their accreditation criteria (Scott, 2008).

Critical thinking is a component of highlevel thinking skills (Woolfolk, 2009), that must be mastered and taught (Muhlisin, Susilo, Amin, \& Rohman, 2016). Critical thinking is reflective and reasonable thinking that is focused on deciding what to believe or do (Ennis, 1985; Ennis, 2011), its purposeful, self-regulatory judgment which results in interpretation, analysis, evaluation, and inference, as well as explanation of the evidential, conceptual, methodological, criteriological, or conceptual considerations upon which that judgment is based (Facione, 1990; 2011). Critical thinking is a propensity and skill to engage in an activity with reflective skepticism (McPeck, 1981). Critical thinking is used to pass judgment on any information, explain the reasons, and able to solve the problem of the unknown (Thomas, 2011), so that each individual is able to understand any information or content on a particular thing (Zane, 2013). Critical thinking is often called independent thinking, reflective thinking, or evaluative thinking (Reid, 2006). Critical Thinking is best understood as the ability of thinkers to take charge of their own thinking (Fahim \& Masouleh, 2012).

Despite differences among of thought and their approaches to defining critical thinking, there exist areas for agreement. The researchers of critical thinking typically agree on the specific abilities and dispositions encompassed by the definition (Lai, 2011), which include: analyzing arguments, claims, or evidence (Ennis, 1985; Facione, 1990; Halpern, 1998; Paul, 1992); making inferences using inductive or deductive reasoning (Ennis, 1985; Facione, 1990; Paul, 1992; Willingham, 2008); judging or evaluating (Case, 2005; Ennis, 1985; Facione, 1990; Lipman, 1988; Tindal \& Nolet, 1995); and making decisions or solving problems (Ennis, 1985; Halpern, 1998; Willingham, 2008). Specific dispositions (behaviors) identified as relevant to critical thinking include asking and answering questions for clarification (Ennis, 1985); identifying assumptions (Ennis, 1985; Paul, 1992); interpreting and explaining (Facione, 1990); reasoning verbally, especially in relation to concepts of likelihood and uncertainty (Halpern, 1998); predicting (Tindal \& Nolet, 1995); and seeing both sides of an issue
(Willingham, 2008). The ability and disposition skills cannot be separated from one another, because it is complementary and will make a person become a whole critical thinker.

Fahim and Masouleh (2012) explained that educational and professional success require nurturing one's consistent internal willingness to think as well as developing one's thinking skills. To do this, the teacher must provide students with as many models, opportunities, exemplars, and explanations as possible in order to help them operationalize their skills. Educators have long been aware of the importance of critical thinking skills as an outcome of student learning (Prayogi, Muhali, Verawati, \& Asy'ari, 2016; Lai, 2011). However, teaching critical thinking remains confusing for many instructors (Bensley \& Murtagh, 2012). This is partly due to the lack of clarity the wide range of methods proposed to best teach critical thinking (Abrami et al., 2008; Bensley \& Murtagh, 2012). Mitrevski and Zajkov (2011) show that the trend of educators in branch countries identified using eighteen models and methods ranging from discussions, demonstrations, project work, to outdoor lesson methods, but there are not explicitly purposed to improve and train critical thinking skills. At higher education level, Bissell and Lemons (2006) ascertained faculties who teach at universities consider critical thinking a primary objective. It is a sad truth that the average college student does not think critically, and not all courses include critical thinking. Thompson (2011) argued that in learning critical thinking requires a holistic approach and should involve a set of appropriate learning models. Therefore, it is necessary to develop a set of specific learning models to promote learner critical thinking skills.

Learning models based on inquiry activities have been widely developed for the purpose to promote students' critical thinking skills, since inquiry is an instructional model that aims to guide about how learners think (Arends, 2012). The processes of scientific creativity in the inquiry activities need to be revealed as a way to promote critical thinking skills of physics prospective teachers. The development of learning models by integrating creativity processes with scientific inquiry activities needs to be explored and developed for that purpose. Creative processes or so-called scientific creativity potentially train the critical thinking ability of learners (Adams, 2006). Aspects of scientific creativity are in the form of problem finding, problem solving, creating hypotheses, design 
experiment, and product design (Turkmen \& Sertkahya, 2015; Ayas \& Sak, 2014; Hu, Shi, Han, Wang, \& Adey, 2010; Aktamis \& Ergin, 2008; Hu \& Adey, 2010). These aspects will later be integrated with the inquiry model into a set of learning model; in this study the learning model is called Inquiry Creativity Process.

This study aims to develop an Inquiry Creative Process (ICP) learning model to promote critical thinking skills of physics prospective teachers. In this study, ICP is seen as a product of learning model. One of the criteria of rich products quality according to Nieveen (1999) is a requirement to meet the criteria of validity. The conceptual framework and validation results of the ICP learning model are revealed in this study.

\section{METHOD}

This study is the preliminary step of development research to produce the InquiryCreative-Process (ICP) learning model with valid criteria. The research design explaining the validation role of the ICP learning model in this study were adapted from Prayogi and Muhali (2015), as described in Figure 1. The research step starts from preliminary research, and then proceed with development planning of model, develop preliminary form of model, arrange hypothetical and conceptual framework of ICP learning model, validation process of model, analysis result of validation, product revision, and the last produce the Inquiry-Creative-Process learning model. The output of this research is to produce the ICP learning model with valid criteria (content and construct) that theoretically can promote critical thinking skills of physics prospective teachers. This study intends to formulate a conceptual framework of ICP learning model that promotes critical thinking skills of physics prospective teachers. The conceptual framework of the ICP learning model was constructed based on theoretical and empirical studies.

The validation method is used to collect the validity data of the ICP learning model. The validation aspects of the ICP model include content validity and construct validity. Refers to Nieveen (1999), content validity is all components that make up the model must be based on need and state-of-the-art of knowledge, and construct validity is meant that all components must be consistently linked between one to another and also logical. Validation is intended to obtain suggestions and feedback from valida- tors. Validators are experts who also as a user of learning model (lecturer). Technically the ICP model validation is done through a focus group discussion (FGD) mechanism. The FGD was followed by a team of researchers and experts involving 5 (five) experts. Feedbacks from the validators in the FGD were then followed up to improve the ICP model.

Learning model is said to have a good degree of validity, if at least the validity level achieved is valid. If the validity level is under valid, then a revision is required.

The reliability of the learning model was calculated using the percentage of agreement equation by Emmer and Millett in Borich (1994). Learning model is said to be reliable if it has percentage of agreement (PA) of $\geq 75 \%$ for each assessment from the validators.

Annotation:

$$
\begin{aligned}
\text { A }= & \text { Frequency of behavior aspects } \\
& \text { where observed by providing high } \\
& \text { frequency. } \\
B= & \begin{array}{l}
\text { Frequency of behavior aspects where } \\
\text { observed by providing low frequency. }
\end{array}
\end{aligned}
$$

\section{RESULTS AND DISCUSSION}

Miles and Huberman (1994) defined a conceptual framework as a visual or written product, one that explains, either graphically or in narrative form, the main things to be studied the key factors, concepts, or variables and the presumed relationships among them. In this study, the conceptual framework of the ICP learning model is constructed based on studies of inquiry models, scientific creativity, and emphasis towards promoting critical thinking skills. The basic principle built as one of the goals of education is to help students foster the skills necessary to be informed consumers of information (DeAngelo et al., 2009), and providing students with the tools to think scientifically is a crucial component of reaching this goal. By focusing on scientific thinking in conjunction with critical thinking, educators may be better able design specific policies through the design of the learning that aim to facilitate the necessary skills students should have when they enter the workforce (Schmaltz et al., 2017).

The ICP is a model developed by integrating the attribution of creative processes or socalled as a scientific creativity of each inquiry syntax. Creativity is required to produce origi- 


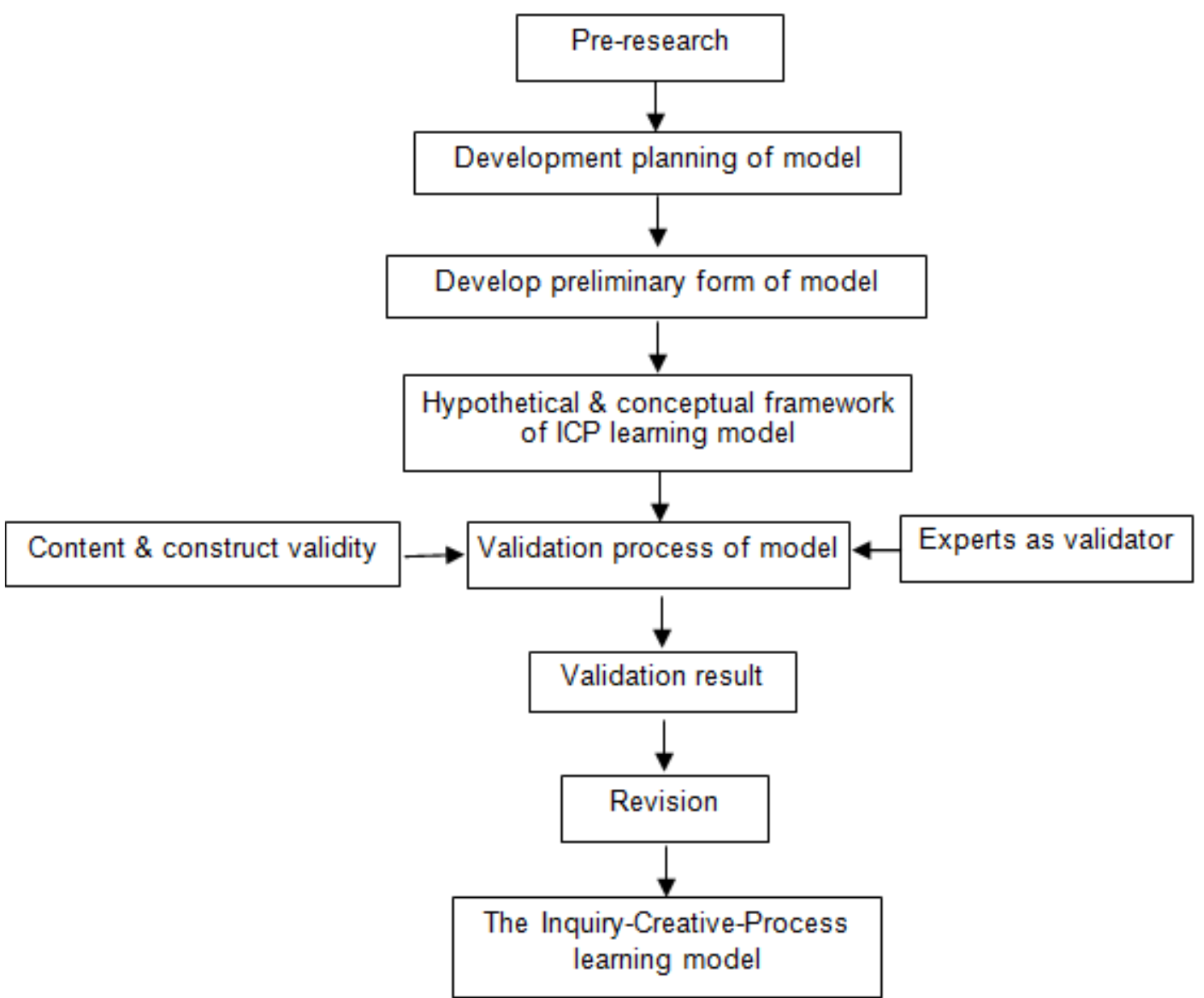

Figure 1. Validation process of ICP learning model

nal ideas (Kleibeuker, DeDreu, \& Crone, 2013). Scientific creativity is a creativity in science learning attributed by an emphasis on problem finding, creating hyphotheses, creatively experiment designing, science creatively problem solving, and creatively product design (Turkmen \& Sertkahya, 2015; Ayas \& Sak, 2014; Hu et al., 2010; Hu \& Adey, 2010; Aktamis \& Ergin, 2008). The assignment of creativity can extend the scope of creative activity, so learners can apply, produce, discover, compare, connect, imagine, and design creative ideas (Rotheram, 2014).

Attributions in scientific creativity are then integrated into scientific inquiry activities. Inquiry based lesson as a learning model according to Arends (2012) should obtain the steps of activities of identify the problems, formulate hypotheses, design the experiments to test hypotheses, formulate explanations, and reflection. Inquiry processes need to be integrated and attributed to scientific creativity for the purpose of training learner critical thinking, as described by Adams (2006) that the creative process (scientific creativity) has the potential to promote critical thinking skills. This integration is also to sharpen the potential to promote thinking through inquiry activities (Arends, 2012).

The framework of developing the InquiryCreative-Process (ICP) learning model is described in Figure 2. Based on the development idea, the hypothetical framework of the InquiryCreative-Process learning model is described in Table 1. Besides of syntax (learning phases), the ICP learning model is attributed by social systems, principles of reaction, support systems, and effects of the model (Joyce \& Weil, 2011).

The social system is formed in the ICP learning model, where the lecturer controls the phases of learning, interaction, and applying the principle of inquiry. However, cooperation, intellectual freedom, thinking, and interacting remain open. The intellectual environment is open to all ideas of the mind, the lecturer encourages the active participation of the learners. The principles of the reaction built, among 


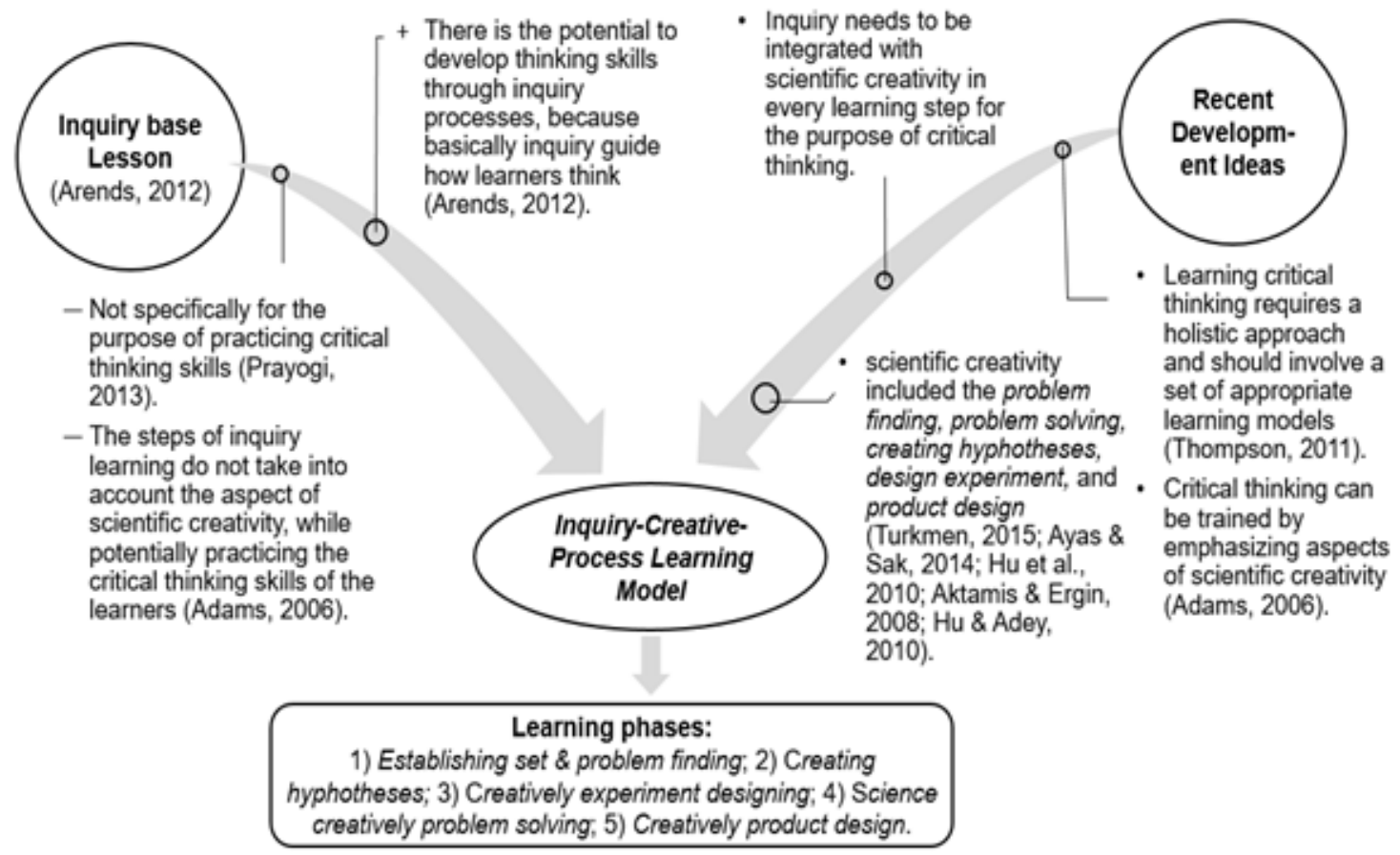

Figure 2. The framework of developing the ICP learning model

Table 1. Hypothetical framework of the ICP learning model

\begin{tabular}{|c|c|}
\hline Learning phase & Learning process \\
\hline $\begin{array}{l}\text { 1. Establishing } \\
\text { set and } \\
\text { problem finding }\end{array}$ & $\begin{array}{l}\text { - Lecturer prepare the lessons and communicate the learning objectives. } \\
\text { - Learners find as many issues as they relate to learning materials. } \\
\text { - Learners choose one core problem to be tested and formulated it. }\end{array}$ \\
\hline $\begin{array}{l}\text { 2. Creating } \\
\text { hyphotheses }\end{array}$ & $\begin{array}{l}\text { - Learners formulate hypotheses according to the selected problem. } \\
\text { - Learners re-examine the relevance of the hypothesis with the formulation } \\
\text { of problems and knowledge that may already exist in their cognition } \\
\text { system. }\end{array}$ \\
\hline $\begin{array}{l}\text { 3. Creatively } \\
\text { experiment } \\
\text { designing }\end{array}$ & $\begin{array}{l}\text { - Learners identify the variables in the hypothesis to be tested. } \\
\text { - Learners define operationally variables that have been identified. } \\
\text { - Learners develop steps of hypothesis testing in the form of creative } \\
\text { experimental procedures based on operational definitions of variables } \\
\text { that have been prepared. }\end{array}$ \\
\hline $\begin{array}{l}\text { 4. Science } \\
\text { creatively } \\
\text { problem solving }\end{array}$ & $\begin{array}{l}\text { - Learners implement the experimental steps that have been prepared. } \\
\text { - Learners check the accuracy of the implementation of experimental steps } \\
\text { that have been done. } \\
\text { - Learners evaluate experimental results based on previously formulated } \\
\text { hypotheses. } \\
\text { - Learners conclude the experimental results. }\end{array}$ \\
\hline $\begin{array}{l}\text { 5. Creatively } \\
\text { product design }\end{array}$ & $\begin{array}{l}\text { - Learners create an experimental result resume that includes detailed } \\
\text { explanations with concept support from relevant sources. }\end{array}$ \\
\hline
\end{tabular}

others the lecturer encourages openness, interaction between learners, and critical thinking, chooses analogies that evoke learners critical thinking skill, facilitates learners to make clear theoretical statements and provides support in generalizing the theory. The support system of the model, where the lecturer understands the intellectual process in learning, the existence of learning tools as supporting processes, including facilities in implementing learning. The main purpose and impact of the ICP learning model, which can improve learners critical thinking skills. Apart from that, as an accompaniment impact of the ICP model, it can train lear- 
ners science process skills.

After the conceptual framework of the ICP learning model is formulated, then the model validation is done on aspects of content validity and constructs validity. The validation processes of ICP learning model were done through focus group discussion (FGD) mechanism involving five experts as validator. The validator assessment of the ICP learning model developed declared valid $(\mathrm{Va}=4.12)$. The results of the validator assessment of the ICP learning model are shown in Table 2 and Figure 3.

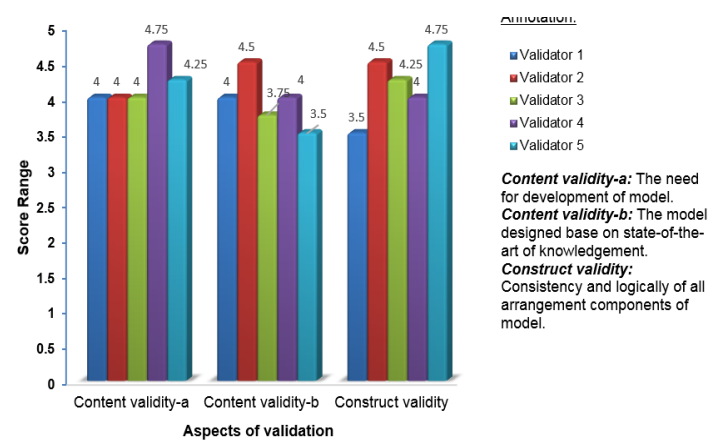

Figure 3. Experts validation result on the ICP

The content validity on aspects of the need for development of the model has a score of Va of 4.20 with valid criteria. This result cannot be separated from the purpose of ICP model development to promote the critical thinking skills of prospective teachers as the need for the main competence of graduates of $21 \mathrm{st}$ century skills. The ICP model has also fulfilled the expectation of the higher education requirement in Indonesia, one of which is to practice critical thinking skills as the demands of student learning needs as contained in the Indonesian National Qualification Framework, and Regulation of the Minister of Research, Technology and Higher Education of the Republic of Indonesia. The development of the ICP model also bridges the gap between the expectation of critical 21st graduate competency needs with the fact that critical thinking skills of prospetive teachers are still relatively low, as previous findings by Prayogi and Muhali (2016).

The aspect of needs in this study also becomes the answer of previous research findings that the model of ICP learning as an alternative model that can be used to promote critical thinking skills of prospective teachers, as explained by Fahim and Masouleh (2012) that educational success require nurturing one's consistent internal willingness to think as well as developing one's thinking skills, and the educator should find ways in order to make learners willing and disposed to think critically. In learning critical thinking requires a holistic approach and should involve a set of appropriate learning models to conduct it (Thompson, 2011). The need for critical thinking in the more general context are if we want learners to be better thinkers, then their critical thinking skills must be developed just like any other skill set. Critical thinking is a philosophical perspective that can help anyone to become more successful. The logic behind this belief is that everyone can benefit from becoming a better thinker and as a result, have greater control over their thinking processes (Egan, 2005).

In this study, the experts as the validator have agreed that the ICP model has met several aspects of needs both globally and internally, and most importantly that the ICP learning model has met the needs aspects in accordance with the regulation of competence to be achieved in learning in Indonesia, for the purpose of critical thinking. Internally in the context of university learning, critical thinking is a crucial skill that students need to develop while at university. It is important for a well-educated person to be able to make well-informed judgments, be able to explain their reasoning and be able to solve unknown problems. Therefore, critical thinking can and should be developed to the learner from the early learning in university (Thomas, 2011).

Table 2. Expert validation results on the ICP learning model

\begin{tabular}{llcc}
\hline & \multicolumn{1}{c}{ Aspects of validation } & Average score & Category \\
\hline $\begin{array}{l}\text { Content } \\
\text { validity }\end{array}$ & $\begin{array}{l}\text { The need for development of model. } \\
\text { The model designed base on state-of-the- } \\
\text { art of knowledge. }\end{array}$ & 4.20 & Valid \\
$\begin{array}{l}\text { Construct } \\
\text { validity }\end{array}$ & $\begin{array}{l}\text { Consistency and logically of all } \\
\text { arrangement components of model. }\end{array}$ & 4.95 & Valid \\
\hline & $\mathrm{Va}$ & 4.12 & Valid \\
& $P A$ & $93.87 \%$ & Reliable, PA $\geq 75 \%$ \\
\hline
\end{tabular}


Content validity on the state-of-the-art aspects has a Va score of 3.95. The development of the ICP model is supported by empirical studies of scientific creativity from recent research references that true scientific creativity can serve as a bridge for critical thinking purposes (Adams, 2006; Turkmen \& Sertkahya, 2015; Ayas \& Sak, 2014; Hu et al., 2010; Aktamis \& Ergin, 2008; Hu \& Adey, 2010). Critical thinking as part of human resources, it can be learned and developed through learning basic science concepts that must be owned by learner (Muhlisin et al., 2016). The learning process depends on our method of learning education because the learning method affects learning goal (Schmaltz et al., 2017; Muhlisin, 2012).

In construct validity component with main aspect is consistency and logically of all arrangement of component of model, the experts as validator give average score of $\mathrm{Va}$ equal to 4.20 with valid criteria. Experts have agreed that the ICP learning model has been consistent and logical in terms of the learning phase, sequence and interrelationships between components in the learning activities. According to Nieveen (1999), if all components are consistently linked to each other (construct validity) then the product is considered to be valid.

The learning phases of the ICP model have been consistent in training critical thinking skills. The problem finding and science creatively problem solving which are the dimensions of scientific creativity, both have a correlation in the context of critical thinking train. The cognitive dimensions of creative thinking certainly correlations with some of the dimensions of critical thinking, this is especially obvious when the students are thinking in the context of problem solving. When the students are thinking in a given context (critical thinking), they make use of various thinking processes (creative thinking). The properties of critical thinking are linked to the creative abilities during problem finding and problem solving (Kousoulas \& Mega, 2008). Creative problem finding is defined as a kind of intellectual trait or ability that is demonstrated in the process of producing and expressing new-found questions in a unique, novel and useful and purposeful way, using existing contexts and experience. It is embodied not only in the quantity, but also in the diversification (types) and in the originality of the problems found (Han, Hu, Liu, Jia, \& Adey, 2013). Therefore, the ICP learning model developed based on the strengthening of the creativity aspects in scientific inquiry will contribute and provide opportunities for the formation of physics prospective teachers who are critical. As well as the critical thinking disposition, when the ICP learning model is implemented in the classroom, it gives an opportunity to strengthen the dispositions of physics prospective teachers critical thinking because the learners' behavior in designed in the ICP model gives them opportunities in asking and answering questions for clarification, identifying assumptions, interpreting and explaining, reasoning verbally, especially in relation to concepts of likelihood and uncertainty, predicting, and seeing both sides of an issue.

Creating hypotheses is a very important part as an aspect of scientific creativity (Jiang \& Thagard, 2014). When learners are faced with problems, they hypothesize and find ways to solve the problem (Arends, 2012), as well as learn to think critically (Alberta Education [AE], 2010). Creatively product design is part of the scientific creativity in which learners are able to design science products from creatively studied (Hu \& Adey, 2010).

This research is in line with previous research by Prayogi, Yuanita, and Wasis (2018a, $2018 b$ ), when the expectations of the model are developed according to needs for development of model, its designed base on state-ofthe-art of knowledge, and consistency and logically of all arrangement components of model, then the contents and constructs of the model are declared valid for the intended purpose. As a comparison, the findings of the study by Suyidno et al. (2017) show that the model intervened by creative processes in learning is valid to developing the creativity and responsibility of physics prospective teachers. While in this study the developed model was based on inquiry which intervened creativity processes for the purpose to developing critical thinking skills of physics prospective teachers. The results in this study are new findings that the intervention of creative processes can promote critical thinking skills of physics prospective teachers.

Theoretically the ICP model has been declared valid, therefore empirical review by applying it to the subject in the learning should be done so that the ICP model is practicality and effectiveness in promoting the critical thinking skills of prospective teachers.

\section{CONCLUSION}

Based on the results of the research in this study, the conceptual framework of the ICP 
learning model has been described by integrating inquiry and scientific creativity processes in learning. The validation results from the experts show that the ICP learning model declared valid on the content validity and construct validity aspects to promote critical thinking skills of prospective teachers.

\section{REFERENCES}

Abrami, P. C., Bernard, R. M., Borokhovski, E., Wade, A., Surkes, M. A., \& Tamim, R. (2008). Instructional interventions affecting critical thinking skills and dispositions: a stage 1 meta-analysis. Review of Educational Research, 78(4), 1102-1134.

Adams, K. (2006). the Sources of Innovation and Creativity. National Center on Education and Economy. USA.

Aktamis, H., \& Ergin, O. (2008). The Effect of Scientific Proccess Skill Education on Student's Scientific Creativity, Science Attitudes, And Academic Achivements. Asia-Facific Forum on Science Learning and Teaching, 9(1), $1-21$.

Alberta Education. (2010). Inspiring Education: A Dialogue with Albertans. Edmonton, AB: Alberta Education.

Arends, R. (2012). Learning to Teach. (9th Ed). New York: McGraw-Hill.

Ayas, B.. \& Sak, U. (2014). Objective Measure of Scientific Creativity: Psychometric Validity of the Creative Scientific Ability Test. Thinking Skills and Creativity, 13, 195-205.

Bensley, D. A., \& Murtagh, M. P. (2012). Guidelines for a scientific approach to critical thinking assessment. Teaching Psychology, 39 (1), 5-16.

Bissell, A. N., \& Lemons, P. P. (2006). A new method for assessing critical thinking in the classroom. BioScience, 56(1), 66-72.

Borich, G. D. (1994). Observation Skills for Effective Teaching. Columbus, $\mathrm{OH}$ : Merrill.

Case, R. (2005). Moving critical thinking to the main stage. Education Canada, 45(2), 45-49.

DeAngelo, L., Hurtado, S., Pryor, J. H., Kelly, K. R., Santos, J. L., \& Korn, W. S. (2009). The American College Teacher: National Norms for the 2007-2008 HERI Faculty Survey. Los Angeles, CA: Higher Education Research Institute.

Egan, B. D. (2005). The role of critical thinking in effective decision making. Access from www. globalknowledge.com

Ennis, R. H. (1985). A logical basis for measuring critical thinking skills. Educational Leadership, 43(2), 44-48.

Ennis. R. H. (2011). The Nature of Critical Thinking: An Outline of Critical Thinking Dispositions and Abilities. Presentation at the Sixth International Conference on Thinking at MIT,
Cambridge, MA.

Facione, P. A. (1990). Critical thinking: A statement of expert consensus for purposes of educational assessment and instruction. Millbrae, CA: The California Academic Press.

Facione, P. A. (2000). The disposition toward critical thinking: Its character, measurement, and relation to critical thinking skill. Informal Logic, 20(1), 61-84.

Facione, P. A. (2011). Critical Thinking. What It Is and Why It's Counts. Measured Reason and the California Academic Press.

Fahim, M., \& Masouleh, N. S. (2012). Critical Thinking in Higher Education: A Pedagogical Look. Theory and Practice in Language Studies, 2(7), 1370-1375.

Halpern, D. F. (1998). Teaching critical thinking for transfer across domains: Dispositions, skills, structure training, and metacognitive monitoring. American Psychologist, 53(4), 449-455.

Han, Q., Hu, W., Liu, J., Jia, X., \& Adey, P. (2013). The Influence of Peer Interaction on Students' Creative Problem-Finding Ability. Creativity Research Journal, 25(3), 248-258.

Hu, W., Shi, QZ., Han, Q., Wang, X. \& Adey, P. (2010). Creative Scientific Problem Finding and Its Developmental Trend. Creativity Research Journal, 22(1), 1-7.

Hu, W., \& Adey, P. (2010). A Scientific Creativity Test for Secondary School Students. International Journal for Science Education, 24(4), 389403.

Jiang, M., \& Thagard, P. (2014). Creative Cognition in Social Innovation. Creativity Research Journal, 26(4), 375-388.

Kleibeuker, S. W., De Dreu, C. K. W., \& Crone, E. A. (2013). The development of creative cognition across adolescence: Distinct trajectories for insight and divergent thinking. Developmental Science, 16, 2-12.

Kousoulas, F., \& Mega, G. (2008). Creative and critical thinking in the context of problem finding and problem solving: A research among students in primary school. Retrieved from http://www.ep.liu.se/ecp/021/vol1/011/ ecp2107011.pdf

Lai, E. R. (2011). Critical Thinking: A Literature Review: Pearson.

Lipman, M. (1988). Critical thinking-What can it be? Educational Leadership, 46(1), 38-43.

McPeck, J. E. (1990). Critical thinking and subject specificity: A reply to Ennis. Educational Researcher, 19(4), 10-12.

Miles, M. B., \& Huberman, A. M. (1994). Qualitative data analysis: An expanded sourcebook (2nd ed.). Thousand Oaks, CA: Sage Publications.

Mitrevski, B., \& Zajkov, O. (2011). Mathematics and Science Teachers' Concept of Critical Thinking. Bulgarian Journal of Physics. 38 (2011), 318-324.

Muhlisin, A., Susilo, H., Amin, M., \& Rohman, F. (2016). Improving critical thinking skills of col- 
lege students through RMS model for learning basic concepts in science. Asia-Pacific Forum on Science Learning and Teaching, 17(1), 1-12.

Muhlisin, A. (2012). Pengembangan Perangkat Pembelajaran IPA Terpadu Berbasis Contextual Teaching and learning (CTL) dengan Model Pembelajaran Kooperatif Tipe Student Achievement Division (STAD) Tema Polusi Udara. Journal of Educational Research and Evaluation, 2, 139-145.

Nieveen, N. (1999). Prototyping to Reach Product Quality. Kluwer: Academic Publisher.

Partnership for 21st Century Skills. (2011). Frame Work for 21st Century Learning. www.p21. org.

Paul, R. W. (1992). Critical thinking: What, why, and how? New Directions for Community Colleges, 1992(77), 3-24.

Peraturan Menteri Riset, Teknologi, dan Pendidikan Tinggi Republik Indonesia Nomor 44 Tahun 2015 tentang Standar Nasional Pendidikan Tinggi.

Prayogi, S., Yuanita, L. \& Wasis. (2018). Critical Inquiry Based Learning: A Model of Learning to Promote Critical Thinking Among Prospective Teachers of Physic. Journal of Turkish Science Education, 15(1), 43-56.

Prayogi S, Yuanita L \& Wasis. (2018). Critical Inquiry Based Learning: Model of Learning to Promote Critical Thinking Ability of Pre-service Teachers. J. Phys.: Conf. Ser. 947 1-6.

Prayogi, S., Muhali, Verawati, N. N. S. P., \& Asy'ari, M. (2016). Pengembangan Model Pembelajaran Aktif Berbasis Inkuiri Untuk Meningkatkan Keterampilan Berpikir Kritis Mahasiswa Calon Guru, Jurnal Pengajaran MIPA, 21(2), 148-153.

Prayogi, S., \& Muhali. (2016). Development of Active-Based-Inquiry Learning Model to Increase Critical Thinking Skills of Students Teachers Candidate of Physics. International Conference on Elementary and Teacher Education (ICETE) 2016. Lombok, 22-23 October 2016.

Prayogi, S., \& Muhali. (2015). Pengembangan model Aktif Berbasis Inkuiri (ABI) untuk mengem- bangkan keterampilan berpikir kritis mahasiswa. Jurnal Prisma Sains, 3 (1), 346-351.

Reid, J. C. (2006). Mengajar Anak Berpikir Kreatif, Mandiri, Mental dan Analitis. Jakarta: Prestasi Pustakaraya.

Rotheram, K. (2014). Teaching, Learning and Creativity (TLC) Model for Science. School Science Review, 95(353), 79-84.

Schmaltz, R. M., Jansen, E., \& Wenckowski, N. (2017). Redefining Critical Thinking: Teaching Students to Think like Scientists. Frontiers in Psychology, 8(459), 1-4.

Scott, S. (2008). Perceptions of Students' Learning Critical Thinking through Debate in a Technology Classroom: A Case Study. Journal of Technology Studies, 34(1), 39-44.

Suyidno, Nur, M., Yuanita, L., \& Prahani, B. K. (2017). Validity of creative responsibility based learning: An innovative physics learning to prepare the generation of creative and responsibility. Journal of Research \& Method in Education, 7(1), 56-61.

Thomas, T. (2011). Developing First Year Students' Critical Thinking Skills. Asian Social Science, 7(4), 26-35.

Thompson, C. (2011). Critical Thinking across the Curriculum: Process over Output. International Journal of Humanities and Social Science, 1(9), 1-7.

Tindal, G., \& Nolet, V. (1995). Curriculum-based measurement in middle and high schools: Critical thinking skills in content areas. Focus on Exceptional Children, 27(7), 1-22.

Turkmen, H., \& Sertkahya, M. (2015). Creative Thinking Skills Analyzes of Vocational High School Students. Journal of Education and Instructional Studies in the World, 5(1), 7484.

Willingham, D. (2008). Critical Thinking: Why Is It So Hard to Teach? Arts Education Policy Review, 109(4), 21-29

Woolfolk, A. (2009). Educational Psychology. New York: Pearson.

Zane, T. (2013). Implementing Critical Thinking with Signature Assignments. Salt Lake: Community College, Sprin. 